\title{
Population Dynamics of Lucerne Aphid
}

\author{
N. D. Makwana*, P. V. Patel, D. B. Nariya and M. F. Acharya \\ Department of Entomology, College of Agriculture, Junagadh Agricultural University, \\ Junagadh, Gujarat, India \\ *Corresponding author
}

A B S T R A C T

Keywords

Lucerne aphid, Aphis craccivora, population dynamics, lucerne

Article Info

Accepted:

20 March 2021

Available Online:

10 April 2021
Investigations on population dynamics of lucerne aphid were carried out under field condition during 2018-19 at Instructional Farm, Junagadh Agricultural University, Junagadh. The activity of aphid, Aphis craccivora was commenced from 2 nd week of February and remained upto 3 rd week of March having peak during 4th week of February in lucerne crop. Simultaneously, higher population of lady bird beetles was observed during 4th week of January to 3rd week of March and showed significantly highly positive correlation with aphid population.

\section{Introduction}

Lucerne (Medicago sativa L.) is known as "Green Gold" or Queen of Forage crops, which is also known as alfalfa and in Arabic meaning "the best". Lucerne is one of the important perennial forage crops, mostly grown for pasturage, silage, soilage, hay, dehydrated meal and medicinal purpose. It contains 4 to 5 times as much protein as forage sorghum and ample quality of vitaminA. It also contains $20.2 \%$ crude protein, 16.2 $\%$ digestible crude protein, $30.1 \%$ crude fibre, $1240 \mathrm{~g}$ calcium and $350 \mathrm{~g}$ phosphorous $/ 100 \mathrm{~kg}$ green fodder and metabolic energy 2.17 $\mathrm{Mcal} / \mathrm{kg}$. In Gujarat, the average production of lucerne is $60-130$ tonnes/ha and average productivity is about $600 \mathrm{~kg} / \mathrm{ha}$ (Anon, 2018) (1). Field crops are found to be infested by various species of aphids. They have a pair of tube like structure on the posterolateral region of the abdomen known as cornicles. Their wings when present are transparent with black lines on them and held in roof like position. There are almost 4,000 identified species of aphid in the world ${ }^{(3)}$ Forbes et al., (1985) About 149 species are known to occur in India (4) Ghosh (1974). Among them, lucerne aphid (Therioaphis trifolli from maculata Buckton), pea aphid (Acyrthosiphon pisum Harris.), groundnut aphid (Aphis craccivora Koch) are commonly found in gujarat. Out of 149 species in India, 32 species are known to be capable of transmitting one or more plant 
viruses such as rosette and mosaic ${ }^{(4)}$ Ghosh (1974). The losses caused by various species of aphid on their host crops are reported by various scientists. ${ }^{(8)}$ Kindler et al., (1971) reported $28 \%$ yield loss in dry matter. The losses in green fodder yield of lucerne due to T. maculata have been reported as $33 \%$ in New Mexico ${ }^{(10)}$ Melton and Wilson (1989). ${ }^{(11)}$ Sorenson et al., (1988) and ${ }^{(6)}$ Irwin et al., (2001) reported $25 \%$ yield loss in hay production. Information on the population dynamics of lucerne aphid is very scanty. Therefore present study will be very useful to know the relationship of aphid population with different weather parameters.

\section{Materials and Methods}

In order to determine the population dynamics of lucerne aphid, experiment was carried out on lucerne Instructional farm, College of Agriculture, JAU, Junagadh during 20182019. To determine the population fluctuation of aphid, ten quadrate of $1 \mathrm{~m} \times 1 \mathrm{~m}$ was selected. The observations were recorded from five apical branches of length $5 \mathrm{~cm}$ from each quadrate, till the maturity of the crop in the morning at weekly intervals. The data, thus obtained were correlated with weather parameters. The weekly meteorological data on different abiotic parameters were obtained from the meteorological observatory of Junagadh Agricultural University, Junagadh. To study the impact of different abiotic factors on pest incidence, a simple correlation between pest population and weather parameters was worked out by using Microsoft Excel 2013.

\section{Results and Discussion}

\section{Infestation due to lucerne aphid}

The data (Table 1) indicated that the incidence of aphid was commenced from 4th week of December i.e. $52^{\text {nd }}$ Standard Meteorological
Week (SMW) and continued till 4th week of March (13th SMW) which ranged from 0.15 to 3.05 (aphid index (AI)/plant). The population of A. craccivora fluctuated during the crop period.

The infestation $(0.15 \mathrm{AI} /$ plant $)$ was started from 4th week of December (52 $\left.{ }^{\text {nd }} \mathrm{SMW}\right)$ and showed the first peak (3.05 AI/plant) during 4th week of February (9 $9^{\text {th }}$ SMW). In subsequent weeks, the incidence was decreased and reached to $0.45 \mathrm{AI} /$ plant during 4 th week of March (13 ${ }^{\text {th }}$ SMW). Beginning from the outbreak to the harvest of the crop pest showed a continuing trend of increasing and after reaching its first peak aphids were continuously decreased.

Close monitoring of this pest indicated that relatively higher (1.30 to $3.05 \mathrm{AI} /$ plant $)$ infestation of aphid was observed during 2nd week of February to 3rd week of March with a peak on 4th week of February. According to (12) Swathi et al., (2015), the highest aphid population remained active from January to March. However, the highest activity of this pest was observed in the first week of March in lucerne crop.

However, the highest activity of this pest was recorded during the first week of March in Lucerne crop. (5) Godwal (2010) reported that the peak population of aphids in Lucerne crop was recorded during February and March. ${ }^{(2)}$ Dalwadi et al., (2007) revealed that the aphid, A. craccivora remained active from midNovember to the end of March with two clear stages of peak periods.

The first peak (2.44 AI/plant) was noticed during the second week of February and the second peak (2.68 AI/plant) during the first week of March in case of Lucerne crop. Overall, the results obtained by the present study follow a more or less similar trend with the earlier reports. 
Table.1 Population of lucerne aphid and ladybird beetle

\begin{tabular}{|c|c|c|c|c|}
\hline Sr. No & SMW & Month & $\begin{array}{c}\text { Mean AI/ } \\
\text { plant }\end{array}$ & $\begin{array}{c}\text { No. of ladybird } \\
\text { beetle/plant }\end{array}$ \\
\hline $\mathbf{1}$ & 51 & December & 0.00 & 0.00 \\
\hline $\mathbf{2}$ & 52 & & 0.15 & 0.00 \\
\hline $\mathbf{3}$ & 1 & & 0.25 & 0.00 \\
\hline $\mathbf{4}$ & 2 & & 0.40 & 0.00 \\
\hline $\mathbf{5}$ & 3 & January & 0.55 & 0.50 \\
\hline $\mathbf{6}$ & 4 & & 0.70 & 1.75 \\
\hline $\mathbf{7}$ & 5 & & 0.85 & 2.25 \\
\hline $\mathbf{8}$ & 6 & & 0.95 & 4.25 \\
\hline $\mathbf{9}$ & 7 & February & 1.30 & 8.00 \\
\hline $\mathbf{1 0}$ & 8 & & 2.15 & 13.25 \\
\hline $\mathbf{1 1}$ & 9 & & 3.05 & 15.00 \\
\hline $\mathbf{1 2}$ & 10 & & 2.85 & 9.50 \\
\hline $\mathbf{1 3}$ & 11 & & 2.50 & 6.00 \\
\hline & & & & \\
\hline $\mathbf{1 4}$ & 12 & & 1.90 & 3.75 \\
\hline $\mathbf{1 5}$ & 13 & & 0.45 & 0.25 \\
\hline
\end{tabular}

Table.2 Correlation of Lucerne aphid with various weather parameter

\begin{tabular}{|c|c|}
\hline Abiotic factors & Correlation \\
\hline Maximum Temperature, ${ }^{0} \mathrm{C}(\operatorname{Max} \mathrm{T})$ & 0.522 \\
\hline Minimum Temperature, ${ }^{0} \mathrm{C}($ Min $\mathrm{T})$ & 0.410 \\
\hline Morning Relative Humidity, \% $\left(\mathbf{R H}_{1}\right)$ & 0.198 \\
\hline Evening Relative Humidity, \% $\left(\mathbf{R H}_{2}\right)$ & 0.181 \\
\hline Rainfall, mm (R) & 0.434 \\
\hline Wind Speed, $\mathbf{k m h r}^{-1}(\mathrm{WS})$ & 0.226 \\
\hline Bright Sunshine Hours, hrday $^{-1}$ (BSS) & -0.165 \\
\hline Significant at $5 \%$ level $(r=0.444)$ & \\
\hline
\end{tabular}

\section{Population of ladybird beetle}

The population (0.50 ladybird beetle/plant) was started from $3^{\text {rd }}$ week of January $\left(3^{\text {rd }}\right.$ SMW) and showed its first peak (15.00 ladybird beetle/plant) during 4th week of February $\left(9^{\text {th }}\right.$ SMW). In subsequent weeks, the population was decreased and reached to $(0.25$ ladybird beetle/plant) during 4th week of
March (13 ${ }^{\text {th }}$ SMW). Starting from the population to the harvest of the crop ladybird beetle showed a continuing trend of increasing and after reaching its first peak they were continuously decreased.

Thus, it is clear from the data (Table 1) that relatively higher (1.75 to 15.00 ladybird beetle/plant) population was observed during 4 th week of January to $3^{\text {rd }}$ week of March 
having the highest peak on $4^{\text {th }}$ week of February.

\section{Effect of weather parameter on lucerne aphid}

The population of aphids A. craccivora was found dependent on environmental factors. The data (Table 2) on the association between aphid infestation and weather factors indicated that there was a positive impact on the appearance of aphid due to MinT (0.410*). There was not any linear correlation either negative or positive between incidences of aphid population form the rest of the physical parameters. However, MaxT (0.522), windspeed (WS) (0.226) and relative humidity (RH1 (0.198), RH2 (0.181) were positive where as bright sunshine hours (BSS) (0.165) were negatively correlated with the incidence of aphid population but the relationship was non-significant. According to ${ }^{(2)}$ Dalwadi et al., (2007) found that the relative humidity and wind speed are positively correlated with the aphid population. ${ }^{(9)}$ Kumar and Kumar (2014) found that there was a negative correlation between aphid and maximum temperature, sunshine hour and wind speed. ${ }^{(7)}$ Jhansi and Verma (2006) also reported more or less similar results that the aphid population was negatively correlated with afternoon relative humidity, maximum and minimum temperature and positively correlated with wind speed. The present study is varied due to the variation in the sowing period or environmental condition during the experimentation.

The incidence of aphid was commenced from 4th week of December i.e $52^{\text {nd }}$ standard meteorological week (SMW) and continued till 4th week of March ( $13^{\text {th }}$ SMW) which was ranged from 0.15 to 3.05 ( aphid index (AI/plant)). The infestation showed its first peak (3.05 AI/ plant) during the 4th week of February $\left(9^{\text {th }}\right.$ SMW $)$. Beginning from the outbreak of pest to the harvest of the crop pest showed a continuing trend of increasing and after reaching its first peak aphids were continuously decreased. Relatively higher (1.75 to 15.00 ladybird beetle/plant) populations of ladybird beetles predators were observed during the 4 th week of January to $3^{\text {rd }}$ week of March having the highest peak on 4th week of February.

A study on the correlation between aphid infestation and weather factors indicated that there was a positive impact on the appearance of aphid due to MinT $(0.410 *)$. There was not any linear correlation either negative or positive between incidences of aphid population for the rest of the physical factors. While an association between ladybird beetle and biotic (aphid infestation) as well as abiotic factors (weather parameters) indicated that there was negative significant impact on the population of ladybird beetle due to bright sunshine hours (BSS) $\left(-0.535^{*}\right)$ while the highly positive significant impact on the population of coccinellids due to aphid population $(0.888 * *)$.

\section{References}

1. Anonymous. Annual Research Report. Main Forage Research Station AAU, Anand, 2018, 2-10.

2. Dalwadi, M. M. Korat, D. M. and Tank, B. D. Population dynamics of major pest of lucerne in rion to weather parameters. Research on Crops, 2007, 8(3): 672- 677.

3. Forbes, A. R., Frazer, B. D. and Chan, C. K. Aphides. In: Handbook of insect rearing vol. I. Ed. Pritam singh and R. F. moore, pub. Elsevier science, 1985, 353359.

4. Ghosh, A. K. Aphids (Homoptera: Insecta) of economic importance in India. Indian Agriculturist, 1974, 18 (2): 81-214.

5. Godwal, B. Population dynamics and varietal preference of aphid, Aphis 
Craccivora (Koch) on Indian bean, Lalab purpureus (Linn.) Sweet. M. Sc. (Ag.) thesis submitted to the SK Rajasthan Agricultural University, Bikaner, Campus- Jobner, 2010.

6. Irwin, J. A., Lloyed, D. L. and Lowe, K. F. Lucerne Biology and genetic improvement an analysis of past activities and future goals in Australia: Australian J. Agril. Res., 2001, 52, 699-712.

7. Jhansi, K. and Varma, Influence of weather factors on population dynamics of pea aphid and Spotted alfalfa aphid on lucerne. Forage Research, 2006, 32(1): 20-25.

8. Kindler, S. D., Kher, W. R. and Ogden, R. L. Influence of pea aphid and spotted alfalfa aphids on the yield of dry matter and chemical composition of lucerne varieties. J. Econ. Ent., 1971, 64 (3): 653-
657.

9. Kumar, A. and Kumar, A. Effect of abiotic and biotic factors on incidence of pests and predator in lucerne, Medicago Sativa (L.). Legume Research, 2014, 38(1): 121-125.

10. Melton, B. and Wilson, M. Registration of "Wilson" alfalfa. Crop sci., 1989, 29 (2): 485-486.

11. Soresen, E. L., Byers, R. A. and Horber, E. K. Breeding for insect resistance. In "Alfaalfa and alfalfa improvement". Agronomy., 1988, 29 : 859-902.

12. Swathi, Y. K., Pandya, H. V., Patel, S. M., Patel, S.D. and Saiyad, M. M. Population dynamics of major insect pests of lucerne, Medicago Sativa (L). International Journal of Plant Protection, 2015; 8(1):112-117.

\section{How to cite this article:}

Makwana, N. D., P. V. Patel, D. B. Nariya and Acharya, M. F. 2021. Population Dynamics of Lucerne Aphid. Int.J.Curr.Microbiol.App.Sci. 10(04): 848-852.

doi: https://doi.org/10.20546/ijcmas.2021.1004.088 